\title{
Evidence-based hydro- and balneotherapy in Hungary-a systematic review and meta-analysis
}

\author{
T. Bender • G. Bálint • Z. Prohászka • P. Géher • I. K. Tefner
}

Received: 25 December 2012 /Revised: 21 March 2013 /Accepted: 31 March 2013 /Published online: 16 May 2013

(C) The Author(s) 2013. This article is published with open access at Springerlink.com

\begin{abstract}
Balneotherapy is appreciated as a traditional treatment modality in medicine. Hungary is rich in thermal mineral waters. Balneotherapy has been in extensive use for centuries and its effects have been studied in detail. Here, we present a systematic review and meta-analysis of clinical trials conducted with Hungarian thermal mineral waters, the findings of which have been published by Hungarian authors in English. The 122 studies identified in different databases include 18 clinical trials. Five of these evaluated the effect of hydro- and balneotherapy on chronic low back pain, four on osteoarthritis of the knee, and two on osteoarthritis of the hand. One of the remaining seven trials
\end{abstract}

T. Bender $\cdot$ P. Géher

Polyclinic of the Hospitaller Brothers of St. John of God,

Budapest, Hungary

T. Bender

Department of Physiotherapy, University of Szeged, Szeged,

Hungary

G. Bálint

National Institute of Rheumatology and Physiotherapy, Budapest, Hungary

\section{Z. Prohászka}

3rd Department of Internal Medicine, Faculty of Medicine,

Semmelweis University, Budapest, Hungary

P. Géher

Medical School, Semmelweis University, Budapest, Hungary

I. K. Tefner

Jozsefvaros Health Care Services, Budapest, Hungary

T. Bender $(\bowtie)$

Budai Irgalmasrendi Korhaz, Hungarian Association of

Balneology, Arpad fejedelem u. 7,

1023, Budapest, Hungary

e-mail: bender@mail.datanet.hu

T. Bender

e-mail: bender.tamas@irgalmas.hu evaluated balneotherapy in chronic inflammatory pelvic diseases, while six studies explored its effect on various laboratory parameters. Out of the 18 studies, 9 met the predefined criteria for meta-analysis. The results confirmed the beneficial effect of balneotherapy on pain with weight bearing and at rest in patients with degenerative joint and spinal diseases. A similar effect has been found in chronic pelvic inflammatory disease. The review also revealed that balneotherapy has some beneficial effects on antioxidant status, and on metabolic and inflammatory parameters. Based on the results, we conclude that balneotherapy with Hungarian thermal-mineral waters is an effective remedy for lower back pain, as well as for knee and hand osteoarthritis.

Keywords Balneotherapy · Spa treatment · Hydrotherapy · Hungary

\section{Introduction}

Balneotherapy has been defined recently as the use of natural mineral waters, natural peloids and mud, and natural sources of different gases $\left(\mathrm{CO}_{2}, \mathrm{H}_{2} \mathrm{~S}\right.$, and $\left.\mathrm{Rn}\right)$ for medical purposes such as prevention, treatment, and rehabilitation (Gutenbrunner et al. 2010). It can be implemented as headout immersion in mineral water; as the application of mudor peloid-packs to body regions; as exposure to gases during bathing and by inhalation; or by drinking mineral water. Balneotherapy can be administered at spas with a special resort environment and atmosphere, or elsewhere (Bender et al. 2005). It is an ancient, traditional treatment modality used in Europe and in other parts of the world (Balint et al. 1993; Konrad 1994) for musculoskeletal (Kamioka et al. 2010), gynaecological (Zámbó et al. 2008), and dermatological (Brockow et al. 2007) conditions (psoriasis in particular), peripheral vascular disease (Pagourelias et al. 2011), and many other disorders (Dubois et al. 2010; Fabry 
et al. 2009). Thermal mineral waters have been used empirically for the treatment of different diseases for centuries. During the last 30 years, a number of controlled trials have demonstrated the efficacy of balneotherapy in treating certain diseases. Although the mode of the action of balneotherapy is still unclear, its efficacy appears confirmed by recent reviews (Harzy et al. 2009; Falagas et al. 2009). Hungary abounds in thermal-mineral waters; in this regard, it is among the richest countries in the world. Approximately 1,300 springs have been registered, and 800 of these are used for medical purposes. Additional balneotherapy resources include five healing caves, five different types of peloid and mud, and post-volcanic discharges of radon and carbon dioxide gases (mofettes). The thermal lake of Hévíz (near Lake Balaton in western Hungary) is the largest of its kind in Europe; its bottom is covered by a special mud, which is also used for medical purposes.

\section{Aims of the study}

Balneology research in Hungary started in the nineteenth century; the Hungarian Balneological Society was founded in 1891. The first tap-water-controlled, double blind trial with balneotherapy treating rheumatoid arthritis (RA) patients was performed in Hungary (and published in Hungarian by Bathory et al. 1981). Another Hungarian trial of a similar design but on osteoarthritis(OA) patients was the first trial to be reported in English (Szucs et al. 1989); it has been followed by a series of controlled trials published by Hungarian authors in the international literature. Some of the Hungarian clinical trials are specialised in that their study populations were recruited from local, ambulatory patients, their design eliminated the placebo effect of the spa environment and atmosphere, and the control subjects were treated with heated tap water (Szucs et al. 1989; Kovacs and Bender 2002; Balogh et al. 2005; Bender et al. 2007; Balint et al. 2007; Zámbó et al. 2008; Kulisch et al. 2009; Olah et al. 2010; Kovacs et al. 2012; Tefner et al. 2012). Recently, Karagülle and Karagülle (2004), as well as Katz et al. (2012) reviewed Turkish and Israeli balneological trials, so to follow suit, we decided to undertake a systematic review of trials by Hungarian authors. Our aim was to provide an overview of Hungarian research into the field of balneotherapy, including both clinical trials and experimental work to study the mode of action of different Hungarian thermal mineral waters. Further, we intended to conduct a meta-analysis of the studies meeting predefined criteria. We chose the relief of pain as the primary outcome measure, whereas secondary outcome parameters included improvement of function, activity level, quality of life, changes in laboratory parameters, and the reduction of analgesic and non steroid anti-inflammatory drug (NSAID) requirements.

\section{Materials and methods}

Data sources

A review and meta-analysis of randomised controlled trials (RCTs) was conducted according to the Quality of Reporting of Meta-analyses (QUOROM) statement (Moher et al. 1999; Clarke 2000). Two authors independently screened the Cochrane Library, as well as the PubMed, Web of Science, Scopus, PED-ro, Web of Knowledge databases.

\section{Data extraction}

The review and meta-analysis was limited to studies of Hungarian thermal mineral waters, published by Hungarian authors in the English-language literature between 1989 and 2012. We searched the above-mentioned literature databases using the following search terms: balneotherapy, spa therapy, thermal water, mineral water, radon bath, radon cave, peloid, underwater traction therapy, hydrotherapy. Two reviewers (T.B. and I.T.) selected clinical trials and extracted their data (study characteristics and results) independently of each other, according to a standard set of criteria. Another investigator (Z.P.) performed the meta-analysis.

\section{Study selection}

We identified all articles discussing hydro- and balneotherapy in Hungary including reports of clinical, experimental, historical, or semantic studies, as well as letters on the effect of mineral water, radon baths, or cave and peloid treatment.

\section{Inclusion criteria for review/meta-analysis}

All clinical trials were included in the systematic review. Studies meeting the following criteria were selected for meta-analysis: any form of balneotherapy or hydrotherapy administered with or without any other treatment; randomised controlled trials comparing balneotherapy with any alternative intervention; full papers reporting Hungarian studies in English; trials carried out in Hungary; studies with at least one symptom-specific outcome measure, such as pain, activity, function, quality of life, or laboratory findings.

Assessment of methodological quality

The internal validity of the clinical studies was assessed using the 11-point van Tulder scale (van Tulder et al. 2003; Furlan et al. 2009). Each criterion was scored 1 (if met) or 0 (if unmet or unknown). Studies scoring lower than $50 \%$ were considered 'low quality' ( 7 studies); those scoring between 50 and $75 \%$ (7 studies) were rated as 'moderate quality', and those over $75 \%$ 'high quality' (4 studies). 
Fig. 1 Flowchart of the review and meta-analysis of randomised controlled trial (RCT) studies

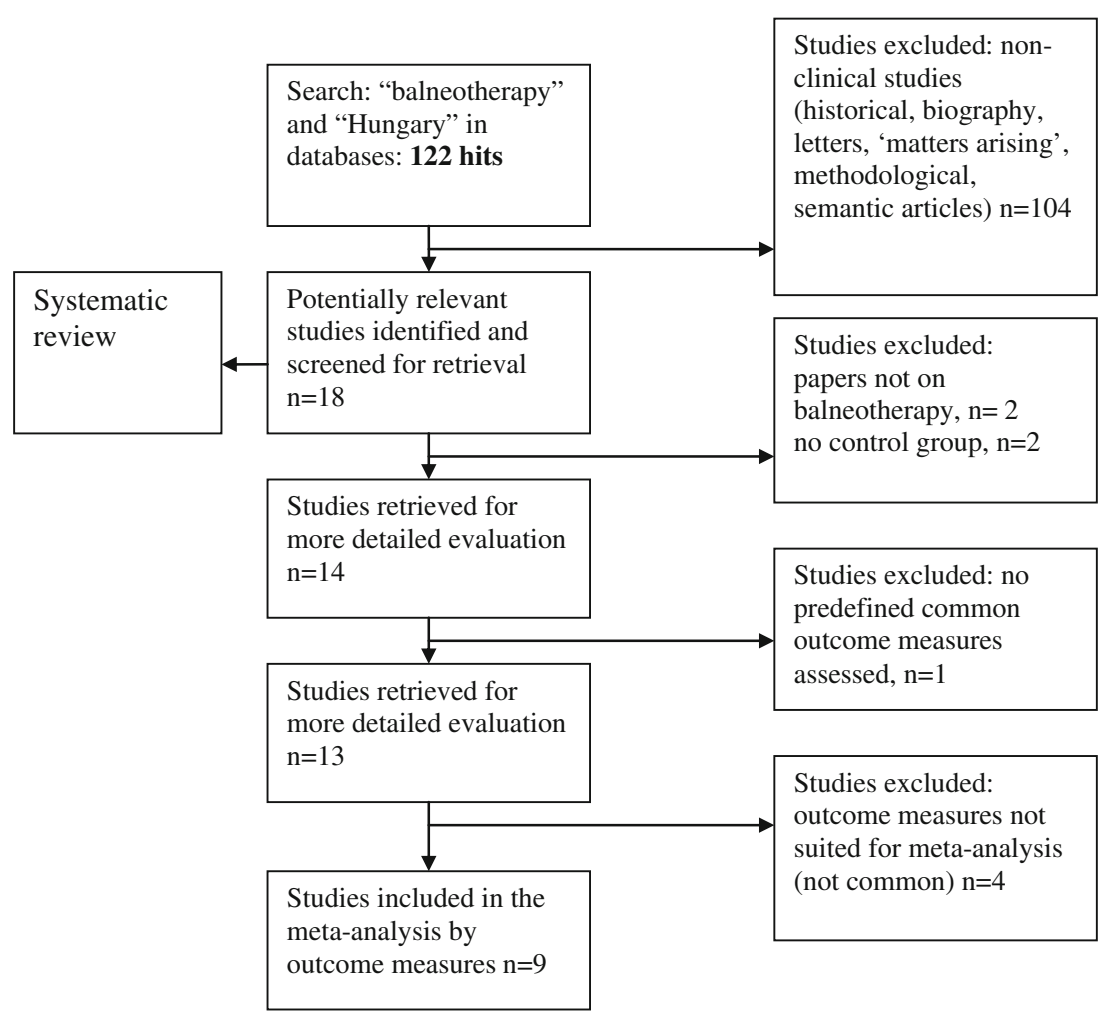

Statistical methods

Mean values and standard deviations (SD), or test statistics were recorded for each of the nine studies, and effect sizes were computed using the standardised mean difference (SMD) technique. The SMD is a scale-free measure of the ratio of the difference in mean outcomes between the groups to the SD of the outcome in the study population. The intervention effect expressed in SMD units is a standardised value rather than the original unit of measure. Sample size and effect sizes were processed with the MedCalc software package (http://www.medcalc.be) with the purpose of generating forest plots as graphical displays of effect size for each study.

\section{Missing data}

Study authors were contacted and missing data obtained through personal communication (Fig. 1).

\section{Results}

Systematic review

The literature search identified 122 studies. Among these, we found 18 possibly relevant studies for data retrieval according to the initial inclusion criteria (clinical trials) (Szucs et al. 1989; Konrad et al. 1992; Kovacs and Bender 2002; Holló et al. 2004; Balogh et al. 2005;
Bender et al. 2007; Balint et al. 2007; Gaal et al. 2008; Olah et al. 2008; Zámbó et al. 2008; Nagy et al. 2009a, b; Kulisch et al. 2009; Olah et al. 2010, 2011; Tefner et al. 2012; Horvath et al. 2012; Kovacs et al. 2012). Data from 1,199 subjects (patients and controls) of the 18 clinical studies were evaluated. Dropouts comprised $7.1 \%(n=85)$ of all patients, and a single adverse event (an allergic reaction to sulphur) occurred in only one study. The main causes of discontinuation were poor compliance and intercurrent disease.

\section{Knee osteoarthritis}

Three randomised, double blind, tap-water-controlled studies were identified, including the first trial of this kind published in English (Szucs et al. 1989). Immersion in thermal mineral water resulted in significant improvement of the clinical indices, namely pain [measured with a visual analogue scale (VAS)] and function [rated with the Western Ontario and McMaster Universities (WOMAC) scale] after balneotherapy (Szucs et al. 1989; Kovacs and Bender 2002; Balint and Szebenyi 1997; Gaal et al. 2008) (Table 1).

\section{Hand osteoarthritis}

The two RCTs (one single blind and one double blind) showed that balneotherapy is beneficial for patients with hand osteoarthritis, in both the short and the long term. This 
Table 1 Effect of balneotherapy on knee osteoarthritis. WOMAC Western Ontario and McMaster Universities index, $R C T$ randomised controlled trial

\begin{tabular}{|c|c|c|c|c|c|c|c|}
\hline Trial & $\begin{array}{l}\text { Study } \\
\text { design }\end{array}$ & $\begin{array}{l}\text { Internal } \\
\text { validity } \\
\text { score }\end{array}$ & Treatment & $n$ & Outcome measures & $\begin{array}{l}\text { Follow- } \\
\text { up period }\end{array}$ & Results \\
\hline $\begin{array}{r}\text { Balint } \\
\text { et al. } \\
2007\end{array}$ & $\begin{array}{r}\text { Double } \\
\text { blind } \\
\text { RCT }\end{array}$ & 7 & $\begin{array}{l}\text { Group 1: immersion in } \\
\text { mineral water }\left(34^{\circ} \mathrm{C}\right) \\
\text { for } 30 \text { mins, } 5 \text { days a } \\
\text { week for } 4 \text { weeks, as a } \\
\text { 20-session treatment } \\
\text { course } \\
\text { Group 2: the same as in the } \\
\text { treatment group, but } \\
\text { using heated tap water }\end{array}$ & 25 & $\begin{array}{l}\text { WOMAC activity, joint } \\
\text { stiffness, pain and } \\
\text { total score }\end{array}$ & 3 months & $\begin{array}{l}\text { WOMAC activity, pain, and } \\
\text { total scores improved } \\
\text { significantly in the } \\
\text { balneotherapy group and the } \\
\text { difference remained } \\
\text { significant at the end of the } \\
\text { follow-up. The same } \\
\text { parameters improved } \\
\text { significantly also in the tap } \\
\text { water group after } \\
\text { balneotherapy, but this } \\
\text { improvement was no longer } \\
\text { detected at the end of the } \\
\text { 3-month follow-up period }\end{array}$ \\
\hline $\begin{array}{l}\text { Szucs } \\
\text { et al. } \\
1989\end{array}$ & $\begin{array}{r}\text { Double } \\
\text { blind } \\
\text { RCT }\end{array}$ & 6 & $\begin{array}{l}\text { Group 1: daily } 20 \text {-min } \\
\text { treatments in } 36^{\circ} \mathrm{C} \\
\text { thermal mineral water } \\
\text { on } 18 \text { occasions } \\
\text { Group } 2 \text { : the same as } \\
\text { in the treatment group, } \\
\text { but using tap water }\end{array}$ & 32 & $\begin{array}{l}\text { Number of patients with } \\
\text { pain at baseline, erythrocyte } \\
\text { sedimentation rate, white } \\
\text { blood cell count }\end{array}$ & 3 weeks & $\begin{array}{l}\text { Number of patients with pain } \\
\text { at baseline, pain and } \\
\text { tenderness decreased in the } \\
\text { treatment group after } \\
\text { treatment }\end{array}$ \\
\hline $\begin{array}{l}\text { Kovacs } \\
\text { and } \\
\text { Bender } 2002\end{array}$ & $\begin{array}{l}\text { Double } \\
\text { blind } \\
\text { RCT }\end{array}$ & 7 & $\begin{array}{l}\text { Group 1: bathing the } \\
\text { painful knee in thermal } \\
\text { mineral water cooled } \\
\text { to } 36^{\circ} \mathrm{C} \text { for } 30 \text { mins } \\
\text { daily, over } 15 \text { days } \\
\text { Group } 2 \text { : the same as in } \\
\text { Group } 1 \text {, but using a } \\
\text { mixture of tap water and } \\
\text { thermal mineral water } \\
\left(36^{\circ} \mathrm{C}\right) \text { of negligible } \\
\text { mineral content? }\end{array}$ & 25 & $\begin{array}{l}\text { Tenderness on palpation, } \\
\text { overall ambulation } \\
\text { capability, patient's and } \\
\text { physician's rating of } \\
\text { therapeutic effect, pain } \\
\text { intensity (using VAS), range } \\
\text { of motion, stair-climbing time }\end{array}$ & 15 weeks & $\begin{array}{l}\text { All monitored parameters } \\
\text { improved in both groups; } \\
\text { however, the magnitude of } \\
\text { the improvement was } \\
\text { significantly greater in } \\
\text { patients treated with thermal } \\
\text { water }\end{array}$ \\
\hline $\begin{array}{l}\text { Gaal et } \\
\text { al. } 2008\end{array}$ & $\begin{array}{l}\text { Prospective } \\
\text { study }\end{array}$ & 3 & $\begin{array}{l}15 \text { balneotherapy sessions } \\
\text { lasting } 30 \text { min each } \\
\text { were administered daily, } \\
\text { using } 33-{ }^{\circ} \mathrm{C} \text { water }\end{array}$ & 38 & $\begin{array}{l}\text { Changes in NSAID/analgesic } \\
\text { consumption, VAS mean } \\
\text { disease severity rated by the } \\
\text { patients, doctor's global } \\
\text { assessment VAS score, the } \\
\text { VAS of pain intensity, } \\
\text { WOMAC scores, mean } \\
\text { cumulative SF-36 (quality } \\
\text { of life) scores }\end{array}$ & $\begin{array}{l}10-14 \\
\text { weeks }\end{array}$ & $\begin{array}{l}\text { All parameters improved } \\
\text { significantly in both } \\
\text { balneotherapy groups. The } \\
\text { favourable effect was } \\
\text { prolonged for } 3 \text { months } \\
\text { after treatment }\end{array}$ \\
\hline
\end{tabular}

was confirmed by the improvement of subjective and objective parameters [grip strength, pinch strength, Health Assessment Questionnaire (HAQ) score, morning joint stiffness, swollen joint count, tender joint count, the Short Form-36 (SF-36), HAQ-DI, Australian/Canadian Hand Osteoarthritis Index (AUSCAN), and Euro Qol Group (EQ5D) scores], without adverse events (Kovacs et al. 2012; Horvath et al. 2012) (Table 2).

\section{Chronic low back pain}

One double blind and two single blind, tap watercontrolled studies were published along with an RCT and a prospective study. The first three studies showed the beneficial effect of thermal mineral water compared with tap water. Both the clinical indices and the quality of life parameters improved significantly in the active treatment groups. The use of tap water as control is a rarity in the literature on the evaluation of mineral waters for low back pain. In a study with 1-year follow-up, analgesic consumption recorded at the last visit was significantly lower in the balneotherapy group compared to the controls (Konrad et al. 1992; Balogh et al. 2005; Gaal et al. 2008; Kulisch et al. 2009; Tefner et al. 2012) (Table 3).

\section{Underwater traction treatment}

Underwater traction (also known as weight bath therapy) was introduced by the Hungarian physician, Károly Moll 
Table 2 Effect of balneotherapy on hand osteoarthritis. VAS Visual analogue scale, HAQ Health Assessment Questionnaire, SF-36 Short Form-36, AUSCAN Australian/Canadian Hand Osteoarthritis Index, EQ5D Euro Qol Group scores

\begin{tabular}{|c|c|c|c|c|c|c|c|}
\hline Trial & Study design & $\begin{array}{l}\text { Internal } \\
\text { validity } \\
\text { score }\end{array}$ & Treatment & $n$ & Outcome measures & $\begin{array}{l}\text { Follow- } \\
\text { up period }\end{array}$ & Results \\
\hline $\begin{array}{c}\text { Horvath } \\
\text { et al. } \\
2012\end{array}$ & $\begin{array}{l}\text { Randomised, } \\
\text { single } \\
\text { blind, } \\
\text { controlled } \\
\text { trial }\end{array}$ & 9 & $\begin{array}{l}\text { Group 1: head-out immersion } \\
\text { in } 38^{\circ} \mathrm{C} \text { thermal mineral } \\
\text { water for } 20 \text { min, five times } \\
\text { a week for } 3 \text { weeks and } \\
\text { standard pulsed magnetic } \\
\text { field therapy applied to the } \\
\text { hands three times a week } \\
\text { over } 3 \text { weeks } \\
\text { Group 2: the same as in Group } \\
\text { 1, but using } 36^{\circ} \mathrm{C} \text { thermal- } \\
\text { mineral water } \\
\text { Group 3: pulsed magnetic field } \\
\text { therapy }\end{array}$ & $\begin{array}{l}21 \\
21 \\
21\end{array}$ & $\begin{array}{l}\text { Pain in the joints of the hands } \\
\text { at rest and upon exertion as } \\
\text { rated by the patient, patient's } \\
\text { and physician's global } \\
\text { assessment, grip strength, } \\
\text { pinch strength, HAQ, } \\
\text { morning joint stiffness (min), } \\
\text { swollen joint count, tender } \\
\text { joint count, SF-36 }\end{array}$ & 13 weeks & $\begin{array}{l}\text { Statistically significant } \\
\text { improvement was observed } \\
\text { in several studied parameters } \\
\text { after treatment and during } \\
\text { follow-up in the thermal } \\
\text { water groups versus the } \\
\text { control group }\end{array}$ \\
\hline $\begin{array}{c}\text { Kovacs } \\
\text { et al. } \\
2012\end{array}$ & $\begin{array}{l}\text { Randomised, } \\
\text { double } \\
\text { blind, } \\
\text { controlled } \\
\text { trial }\end{array}$ & 8 & $\begin{array}{l}\text { Group 1: head-out immersion } \\
\text { for } 20 \text { min per session in a } \\
\text { bath-tub filled with thermal } \\
\text { mineral water, on } 15 \\
\text { occasions altogether, over a } \\
\text { period of } 3 \text { weeks. The } \\
\text { temperature of the water was } \\
37^{\circ} \mathrm{C} \text {. } \\
\text { Group } 2 \text { : the same as in the } \\
\text { treatment group, but in tap } \\
\text { water of the same } \\
\text { temperature }\end{array}$ & 24 & $\begin{array}{l}\text { Pain VAS, morning joint } \\
\text { stiffness (min), grip strength, } \\
\text { HAQ-DI, AUSCAN (total, } \\
\text { pain, stiffness, physical } \\
\text { function), EQ5D, EQVAS } \\
\text { (quality of life) }\end{array}$ & 6 months & $\begin{array}{l}\text { At the end of treatment, the } \\
\text { improvement was more } \\
\text { pronounced in the patient } \\
\text { group treated with thermal } \\
\text { mineral water. The difference } \\
\text { between the groups was } \\
\text { significant regarding pain } \\
\text { VAS and EQVAS, both } \\
\text { immediately and } 3 \text { months } \\
\text { after treatment. The same } \\
\text { was observed regarding } \\
\text { AUSCAN after } 3 \text { months, as } \\
\text { well as regarding HAQ after } \\
3 \text { and } 6 \text { months }\end{array}$ \\
\hline
\end{tabular}

(Moll 1953) In a controlled study of patients suffering from cervical and lumbar degenerative disc disease, underwater traction reduced pain intensity (VAS), increased spinal mobility, and improved the quality of life (Olah et al. 2008) (Table 4).

\section{Chronic pelvic inflammatory disease}

A 3-week course of balneotherapy was beneficial as an addon intervention in the management chronic pelvic inflammatory disease. The improvement of clinical parameters was significantly greater with thermal mineral water than with tap water (Zámbó et al. 2008) (Table 5).

\section{Physiological effects}

Effect of radon baths on the endocrine system In Hungary, some mineral waters contain small amounts of radon, which had no significant effect on endocrine parameters. According to another study, radon speleotherapy had a minor influence on the endocrine system in patients suffering from chronic lung disease (Nagy et al. 2009a, b) (Table 6).
Effects on inflammatory and metabolic indices Four studies investigated changes in inflammatory and metabolic indices. One controlled study found that mineral water had a more beneficial effect on antioxidant status than tap water. In hypertensive patients, the differences between baseline and post-treatment $\mathrm{HbA}_{1 \mathrm{C}}$ levels were more pronounced in the balneotherapy group than in the controls. The C-reactive protein levels in hypertensive patients decreased significantly after balneotherapy. In a study of patients with psoriasis, no change of beta-endorphin levels could be detected during balneo-phototherapy (Holló et al. 2004; Bender et al. 2007; Olah et al. 2010, 2011) (Table 7)

Meta-analysis

Of the 18 clinical trials, 9 were excluded; 2 studies lacked a proper control group (Gaal et al. 2008; Holló et al. 2004); 1 study measured the effect of underwater traction and not that of balneotherapy (Olah et al. 2008). One additional study evaluated radon cave therapy and not balneotherapy (Nagy et al. 2009a, b). Following a more detailed review of these provisionally selected articles, a further five papers were excluded for 


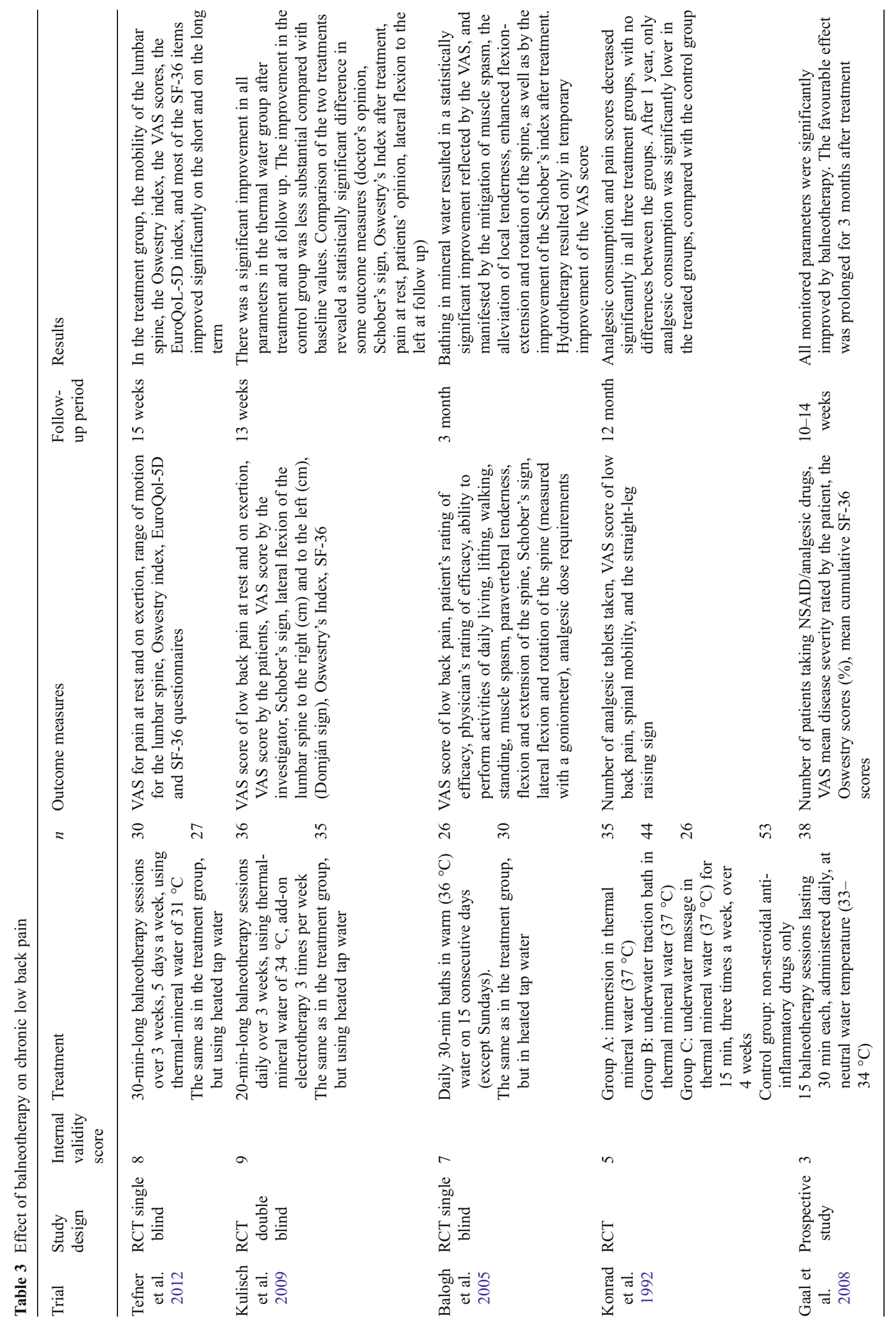




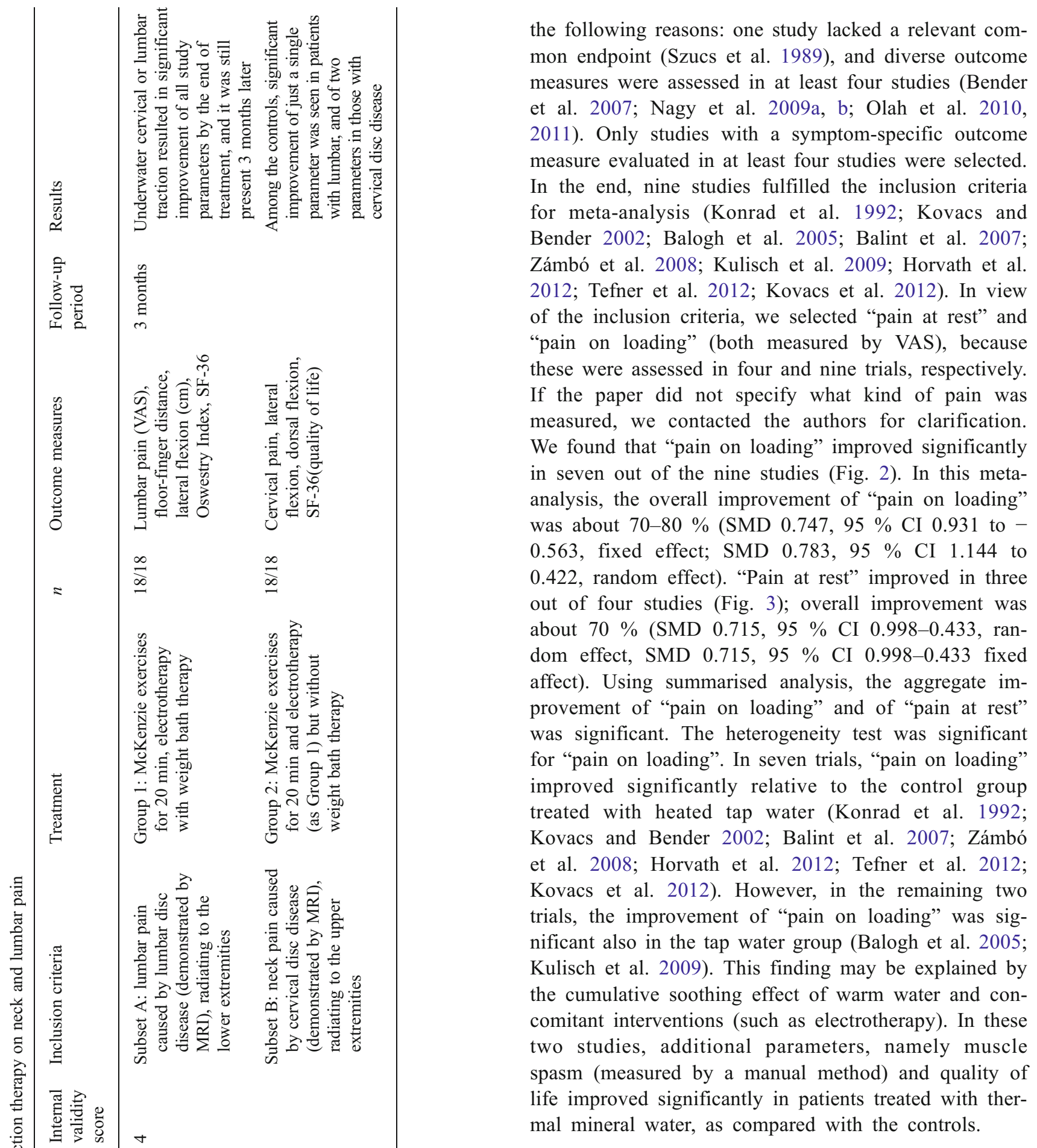

\section{Discussion}

In Hungary, balneotherapy has long been used as a traditional treatment, for the country is rich in thermal mineral waters. The majority of the published papers focus on balneotherapy for musculoskeletal disorders, although an increasing number of publications report its application in other clinical fields. Additional applications include 
Table 5 Effect of balneotherapy on chronic inflammatory pelvic disease

\begin{tabular}{|c|c|c|c|c|c|c|c|}
\hline Trials & Study design & $\begin{array}{l}\text { Internal } \\
\text { validity } \\
\text { score }\end{array}$ & Treatment & $n$ & Outcome measures & $\begin{array}{l}\text { Follow- } \\
\text { up }\end{array}$ & Results \\
\hline $\begin{array}{l}\text { Zámbó } \\
\text { et al. } \\
2008\end{array}$ & $\begin{array}{l}\text { Randomised, } \\
\text { double } \\
\text { blind }\end{array}$ & 6 & $\begin{array}{l}\text { Daily baths of } \\
20 \text { mins } \\
\left(38.8^{\circ} \mathrm{C}\right) \text { on } \\
\text { ten occasions } \\
\text { The same as in } \\
\text { treatment } \\
\text { group, but } \\
\text { using heated } \\
\text { tap water }\end{array}$ & 20 & $\begin{array}{l}\text { Pain (VAS) elicited by palpating the } \\
\text { uterus, the adnexes and the } \\
\text { parametrium, parametrial and adnexal } \\
\text { mass; psychic status (VAS); } \\
\text { ultrasound Doppler index }\end{array}$ & 3 weeks & $\begin{array}{l}\text { In comparison with tap water, } \\
\text { treatment with mineral water } \\
\text { accomplished significantly greater } \\
\text { improvement, as reflected by the } \\
\text { relief of pain elicited by handling the } \\
\text { uterus, and by the improvement of } \\
\text { psychological status }\end{array}$ \\
\hline
\end{tabular}

inhalation treatment for laryngeal diseases and oncology rehabilitation programs, whereas the drug sparing effect of balneotherapy can be utilized in psychiatry (Dubois et al. 2010). Furthermore, it is useful in cardiovascular rehabilitation, especially because of the positive haemorheological effects of natural carbonated mineral water (Pagourelias et al. 2011). In the international medical literature, Kamioka et al. (2010) reviewed hydro- and balneotherapy papers published between 1990 and 2008. The authors could not draw any conclusions regarding balneotherapy, because of the diversity of outcome measures, the lack of proper control groups, and poor study design. Falagas et al. (2009) reviewed balneotherapy studies excluding hydrotherapy trials. They selected 29 RCTs of 1,720 patients; 8 of these evaluated balneotherapy in osteoarthritis, 4 in fibromyalgia, 4 in ankylosing spondylitis, 4 in rheumatoid arthritis, 3 each in psoriatic arthritis and chronic low back pain, and 1 in Parkinson's disease. In 17 trials, pain decreased significantly compared to the control group, whereas in 8 trials there was no difference. The analgesic effect of balneotherapy lasted for 3 months in 9 studies of longer duration. In their metaanalysis of studies evaluating balneotherapy in osteoarthritis (including the study by Kovacs and Bender 2002), Verhagen et al. (2008) found only a few well-designed trials using appropriate statistical methods. The authors concluded that the effect of balneotherapy is "unproven" and called for additional well-designed studies. The systematic review by Forestier and Françon (2008) led to similar conclusions regarding balneotherapy trials of knee osteoarthritis. The small number of included patients and the poor methodology precluded any conclusions regarding the decrease of pain, improvement of function and quality of life following balneotherapy of patients with osteoarthritis of the knee. Harzy et al. (2009) reviewed 9 RCTs evaluating the balneotherapy of knee osteoarthritis. They found that pain measured by VAS decreased significantly for 8-12 weeks in six RCTs and for 20-24 weeks in two RCTs; articular function also improved significantly over the longer term. Recently, Forestier et al. (2010) published a multicenter
RCT (conducted at three study sites) of 382 patients with knee joint osteoarthritis. The active group was treated with baths in thermal mineral water for 18 days in addition to massage, underwater massage, and mud packing. The control group received drugs and exercised. Balneotherapy was significantly superior in improving pain and joint function as measured by WOMAC, even after 6 months of follow-up. Pittler et al. (2006) published their meta-analysis of 5 RCTs (of 580 patients) appraising the effect of balneotherapy in chronic back pain. Active treatment comprised complex balneotherapy in 5 RCTs, but only immersion in thermal mineral water in one RCT. The controls - patients on the waiting list for balneotherapy - received drugs and exercised. The author rated the results as "encouraging" regarding the decrease of pain, and emphasised the need for further research. Since 2005, three tap water-controlled RCTs, all by Hungarian authors, have evaluated the effect of balneotherapy on back pain (Tefner et al. 2012; Kulisch et al. 2009; Balogh et al. 2005). The physical effect of temperature, buoyancy, and hydrostatic pressure, etc. during balneo- and hydrotherapy are well-established (Sramek et al. 2000). The chemical effects of balneotherapy, such as the absorption of minerals through the skin, is scarcely documented (Shani et al. 1985). The mode of action of thermal-mineral water treatment has been discussed in several papers, of which the work of Fioravanti et al. (2011) provides the most comprehensive overview. Only two countries-Turkey and Israel-have reviewed domestic balneotherapy research. Karagülle and Karagülle (2004) analysed 15 papers on studies evaluating the treatment of various musculoskeletal diseases at eight Turkish spa resorts. One of these studies examined the effect of mud pack treatment, whereas the others appraised that of bathing in thermal mineral water. The analgesic effect was significant in all balneotherapy trials. Katz et al. (2012) reviewed the research focused on Dead Sea balneo- and climatotherapy. Bathing in Dead Sea water and the exposure to UV radiation has a beneficial effect on psoriasis. Dead Sea balneo- and climatotherapy decreases pain, improves joint function and quality of life in rheumatoid arthritis, in 


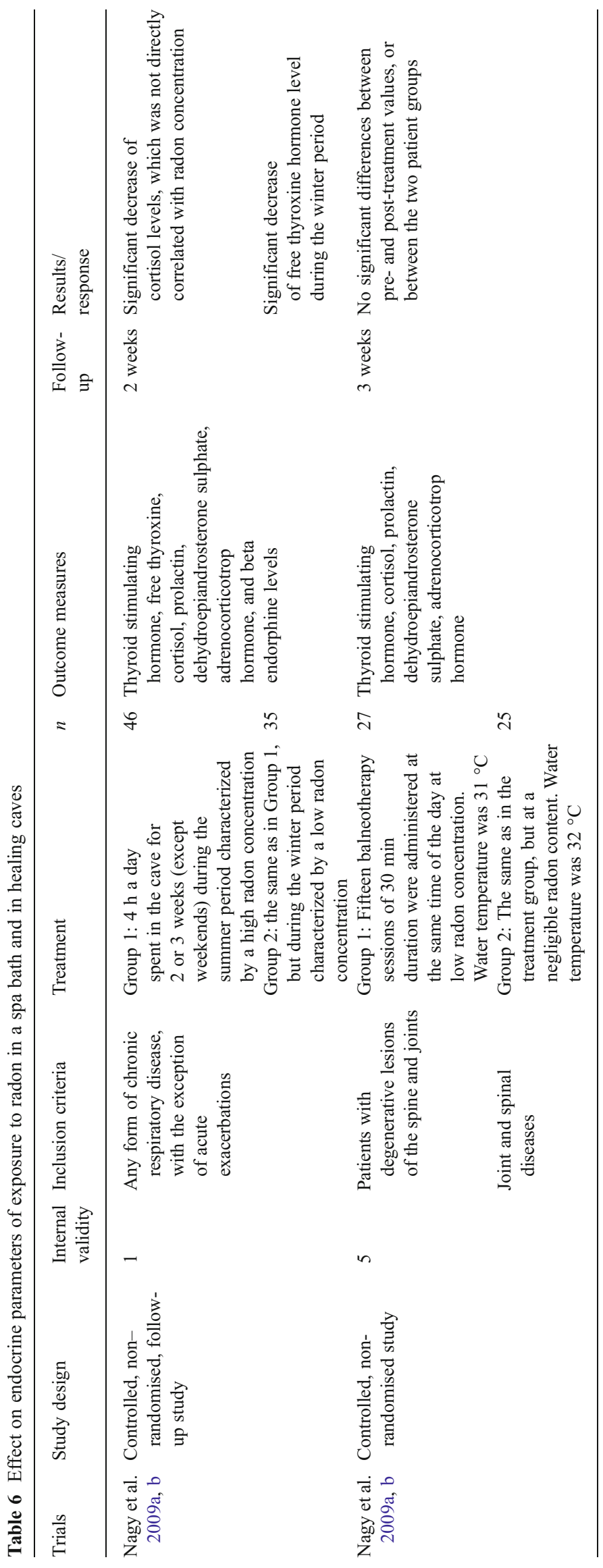




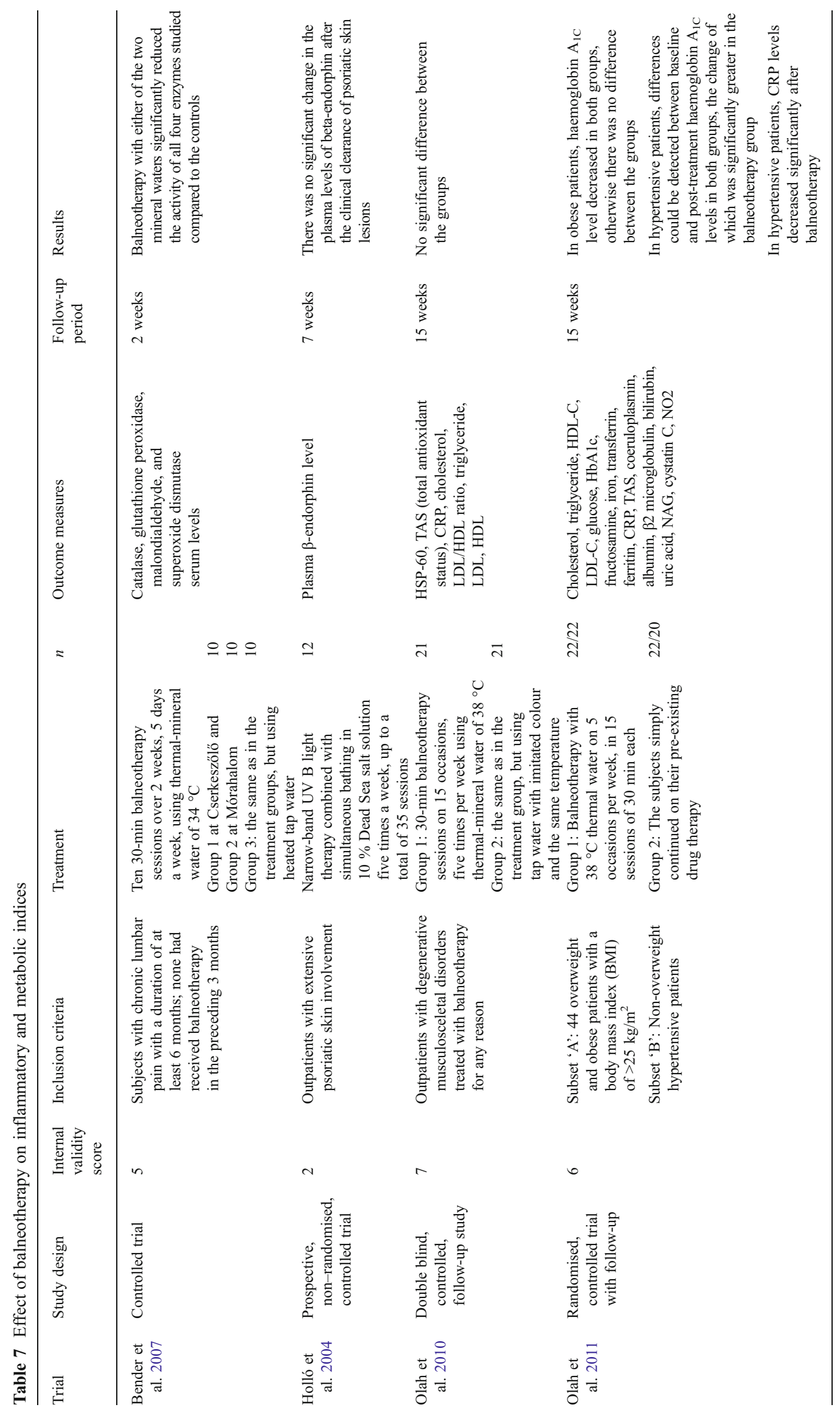




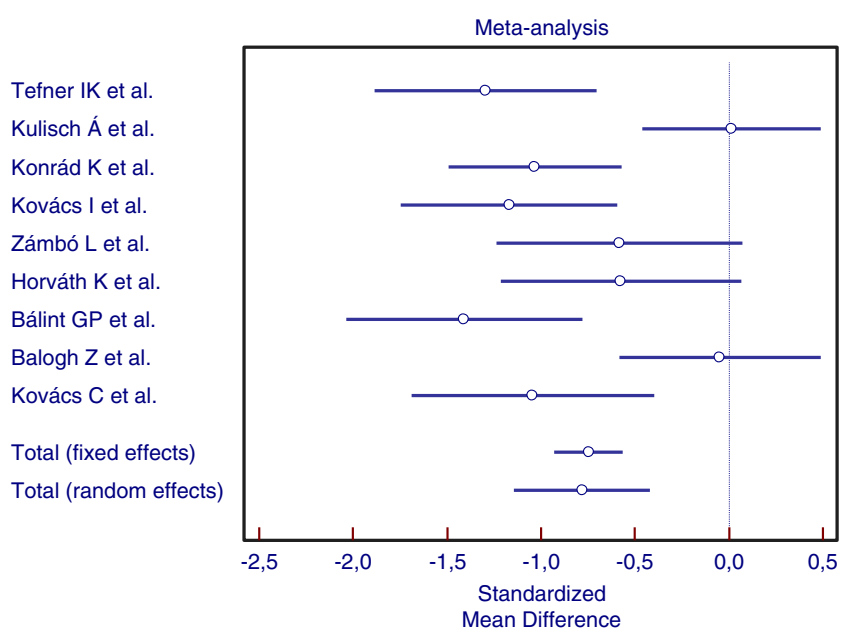

Fig. 2 Visual analogue scale (VAS) intensity of pain on loading

ankylosing spondylitis, as well as in psoriatic arthritis and in osteoarthritis. Dead Sea balneotherapy did not increase blood pressure, as shown by ambulatory blood pressure monitoring (ABPM). Although our selection criteria identified only 18 Hungarian studies, all the remaining Hungarian papers, letters, and methodology publications appeared in important international journals (Balint and Szebenyi 1997; Bender et al. 2001, 2002; Somlai et al. 2007; Gerencsér et al. 2010; Varga 2011; Kavasi et al. 2011a, b; Varga 2012; Szendi et al. 2012). The Hungarian study of underwater traction ("weight-bath") confirmed earlier biomechanical findings (Kurutz and Bender 2010).

Based on the numerous Hungarian and non-Hungarian tap water-controlled studies, we can state that thermal mineral water alleviates pain caused by different musculoskeletal diseases regardless of the qualitative and quantitative composition of mineral water. This finding may suggest that the minerals might act on cutaneous nerve endings, and thereby achieve long-lasting gate control; experimental skin

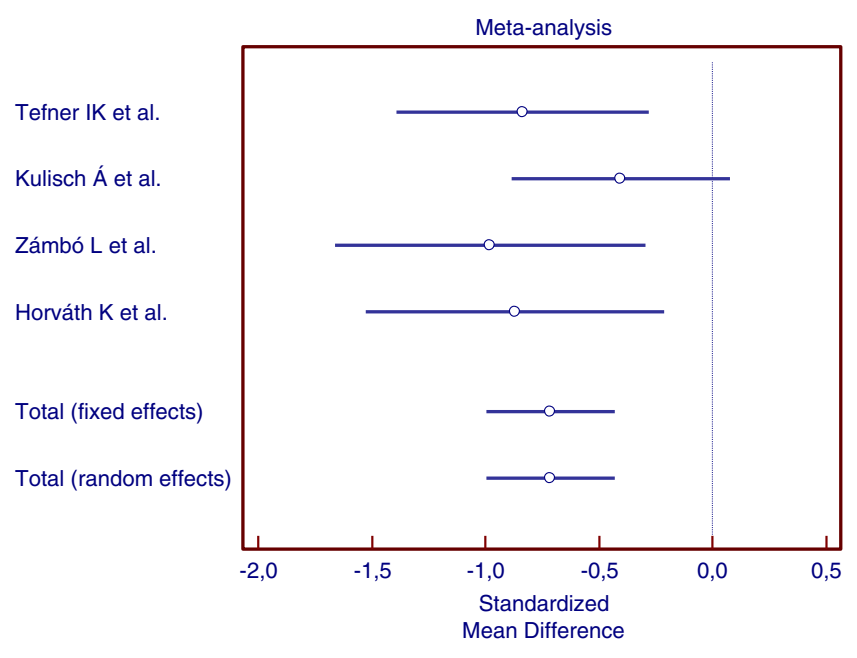

Fig. 3 VAS intensity of pain at rest biopsy studies could answer this question. The first tap water-controlled trial studying the effect of balneotherapy in chronic inflammatory gynaecological diseases was published by Hungarian authors. There are additional Hungarian studies about the effect of balneotherapy on the antioxidant system, as well as on inflammatory and metabolic parameters, which have been shown to remain normal even in patients with hypertension and obesity. The effects of exposure to radon in caves and in mineral water on some endocrine parameters were also studied. The Hungarian study of vertical underwater traction (weight bath-a balneotherapy modality introduced in the 1950s) was the first in the literature to demonstrate the clinical efficacy of this treatment in cervical and lumbar disc disease under controlled study conditions. We are aware, however, that only well-designed and implemented trials can prove or refute the efficacy of balneotherapy. Hungarian authors were the first to use balneotherapy with heated tap water as placebo control in a double-blind controlled study. This was possible because most of the Hungarian thermal mineral waters do not have a characteristic smell, and their colour can be imitated when necessary. Hungarian authors have aspired to conduct trials under ordinary, non-spa conditions, in local, ambulatory patients, keeping them in their everyday environment. The abundance of thermal springs in Hungary made it possible to realise this ambition.

\section{Limitations of the study}

Several of the included studies had small patient populations, and their outcome measures were heterogeneous. The studies were diverse in terms of the type, intensity, and duration of treatments, as well as in regard of the methodology and timing of clinical assessments. The lack of sponsors is a serious problem even for well-designed trials. The selection of a suitable control group may be difficult, and the blinded use of tap water is often impossible. Accordingly, and as shown by van Tulder scores, studies performed 10-20 years ago were of poor quality. In the last 10 years, the design and implementation of RCTs conforms to consensus guidelines. The only common feature of the analysed studies was their primary outcome measure; between-study heterogeneity and methodological flaws prevented the analysis of their secondary endpoints. Occasionally, the type of pain (i.e. pain at rest, at loading or on weight bearing) was ascertained by personal communication with the authors, and not from the information presented in the results section of the papers.

Publication bias

Only studies published in English were included. Therefore, a number of reports in Hungarian-including that of the first 
double-blind, tap water-controlled study of balneotherapy in rheumatoid arthritis - were disregarded.

\section{Conclusion}

Our review and the meta-analysis of nine articles appear to confirm that the studied Hungarian thermal mineral waters significantly reduce pain in degenerative joint and spinal disease, as well as osteoarthritis of the hand and knee, and that they also alleviate chronic low back pain.

\section{Conflict of interest None.}

Open Access This article is distributed under the terms of the Creative Commons Attribution License which permits any use, distribution, and reproduction in any medium, provided the original author(s) and the source are credited.

\section{References}

Balint G, Szebenyi B (1997) Non-pharmacological therapies in osteoarthritis. Baillieres Clin Rheumatol 11:795-815

Balint G, Bender T, Szabó E (1993) Spa treatment in arthritis. J Rheumatol 20:1623-1625

Balint GP, Buchanan WW, Adám A, Ratkó I, Poór L, Bálint PV, Somos E, Tefner I, Bender T (2007) The effect of the thermal mineral water of Nagybaracska on patients with knee joint osteoarthritis - a double blind study. Clin Rheumatol 26:890-894

Balogh Z, Ordögh J, Gász A, Német L, Bender T (2005) Effectiveness of balneotherapy in chronic low back pain - a randomized singleblind controlled follow-up study. Forsch Komplementarmed Klass Naturheilkd 12:196-201

Bathory G, Meretey K, Korda J, Gasztonyi G, Bohm U, Gorgényi F, Balint G (1981) Kettős vak kísérlet a kiskunhalasi termálvíz terápiás hatásának mérésére rheumatoid arthritises betegeken. Magyar Reumatológia 22:30-36

Bender T, Géher P, Balint G (2001) Nonpharmacologic treatment of musculoskeletal disease. Clin J Pain 17:278

Bender T, Balint PV, Balint GP (2002) A brief history of spa therapy. Ann Rheum Dis 61:949, author reply 949-950

Bender T, Karagülle Z, Balint GP, Gutenbrunner C, Balint PV, Sukenik S (2005) Hydrotherapy, balneotherapy, and spa treatment in pain management. Rheumatol Int 25:220-224

Bender T, Bariska J, Vaghy R, Gomez R, Kovács I (2007) Effect of balneotherapy on the antioxidant system-a controlled pilot study. Arch Med Res 38:86-89

Brockow T, Schiener R, Franke A, Resch KL, Peter RU (2007) A pragmatic randomized controlled trial on the effectiveness of lowconcentrated saline spa water baths followed by ultraviolet $\mathrm{B}(\mathrm{UVB})$ compared to UVB only in moderate to severe psoriasis. $\mathrm{J}$ Eur Acad Dermatol Venereol 21:1027-1037

Clarke M (2000) The QUORUM statement. Lancet 355:756-757

Dubois O, Salamon R, Germain C, Poirier MF, Vaugeois C, Banwarth B, Mouaffak F, Galinowski A, Olié JP (2010) Balneotherapy versus paroxetine in the treatment of generalized anxiety disorder. Complement Ther Med 18:1-7

Fabry R, Monnet P, Schmidt J, Lusson JR, Carpentier PH, Baguet JC, Dubray C (2009) Clinical and microcirculatory effects of transcutaneous $\mathrm{CO} 2$ therapy in intermittent claudication.
Randomized double-blind clinical trial with a parallel design. Vasa 38:213-24

Falagas ME, Zarkadoulia E, Rafailidis PI (2009) The therapeutic effect of balneotherapy: evaluation of the evidence from randomised controlled trials. Meta-analysis. Int J Clin Pract 63:1068-1084

Fioravanti A, Cantarini L, Guidelli GM, Galeazzi M (2011) Mechanisms of action of spa therapies in rheumatic diseases: what scientific evidence is there? Rheumatol Int 31:1-8

Forestier R, Françon A (2008) Crenobalneotherapy for limb osteoarthritis: systematic review and metodological analysis. Joint Bone Spine 75:138-48

Forestier R, Desfour H, Tessier JM, Francon A, Foote AM, Genty C, Rolland C, Roques CF, Bosson JL (2010) Spa therapy in the treatment of knee osteoarthritis: a large randomised multicentre trial. Ann Rheum Dis 69:660-665

Furlan A, Pennick V, van Tulder M, Editorial Board of the Cochrane Back Review Group (2009) Updated method guidelines for systematic reviews in the Cochrane Back Review Group. Spine 34:1929-1941

Gaal J, Varga J, Szekanecz Z, Kurkó J, Ficzere A, Bodolay E, Bender T (2008) Balneotherapy in elderly patients: effect on pain from degenerative knee and spine conditions and on quality of life. Isr Med Assoc J 10:365-369

Gerencsér G, Murányi E, Szendi K, Varga C (2010) Ecotoxicological studies on Hungarian peloids (medicinal muds). Appl Clay Sci 50:47-50

Gutenbrunner C, Bender T, Cantista P, Karagülle Z (2010) A proposal for a worldwide definition of health resort medicine, balneology, medical hydrology and climatology. Int J Biometeorol 54:495-507

Harzy T, Ghani N, Akasbi N, Bono W, Nejjari C (2009) Short- and long-term therapeutic effects of thermal mineral waters in knee osteoarthritis: a systematic review of randomized controlled trials. Clin Rheumatol 28:501-507

Holló P, Bender T, Marschalkó M, Gonzalez R, Barna I, Horváth A (2004) No significant change of plasma beta-endorphin levels of psoriasis patients after synchronous balneophototherapy. Photodermatol Photoimmunol Photomed 20:205-209

Horvath K, Kulisch A, Nemeth A, Bender T (2012) Evaluation of the effect of balneotherapy in patients with osteoarthritis of the hands: a randomized controlled single-blind follow-up study. Clin Rehabil 26:431-441

Kamioka H, Tsutani K, Okuizumi H, Mutoh Y, Ohta M, Handa S, Okada S, Kitayuguchi J, Kamada M, Shiozawa N, Honda T (2010) Effectiveness of Aquatic Exercise and Balneotherapy: A Summary of Systematic Reviews Based on Randomized Controlled Trials of Water Immersion Therapies. J Epidemiol 20:2-12

Karagülle MZ, Karagülle M (2004) Forsch Komplementarmed (in German). Klass Naturheilkd 11:33-41

Katz U, Shoenfeld Y, Zakin V, Sherer Y, Sukenik S (2012) Scientific evidence of the therapeutic effects of Dead Sea treatments: a systematic review. Semin Arthritis Rheum 42:186-200

Kavasi N, Kobayashi Y, Kovács T, Somlai J, Jobbágy V, Nagy K, Deák E, Berhés I, Bender T, Ishikawa T, Tokonami S, Vaupotic J, Yoshinaga S, Yonehara H (2011a) Effect of radon measurement methods on dose estimation. Radiat Prot Dosimetry 145:224-232

Kavasi N, Kovács T, Somlai J, Jobbágy V, Nagy K, Deák E, Berhés I, Bender T (2011b) Comparison of urinary excretion of radon from the human body before and after radon bath therapy. Radiat Prot Dosimetry 146:27-30

Konrad K (1994) The way forward for balneotherapy. Br J Rheumatol 33:301

Konrad K, Tatrai T, Hunka A, Vereckei E, Korondi I (1992) Controlled trial of balneotherapy in treatment of low back pain. Ann Rheum Dis $51: 820-822$

Kovacs I, Bender T (2002) The therapeutic effects of Cserkeszölö thermal water in osteoarthritis of the knee: a double blind, controlled, follow-up study. Rheumatol Int 21:218-221 
Kovacs C, Pecze M, Tihanyi Á, Kovács L, Balogh S, Bender T (2012) The effect of sulphurous water in patients with osteoarthritis of hand. Double-blind, randomized, controlled follow up study. Clin Rheumatol 31:1437-1442

Kulisch A, Bender T, Németh A, Szekeres L (2009) Effect of thermal water and adjunctive electrotherapy on chronic low back pain:a double-blind, randomized, follow-up study. J Rehabil Med 41:73-79

Kurutz M, Bender T (2010) Weightbath hydrotraction treatment: application, biomechanics, and clinical effects. J Multidiscip Health 3:19-27

Moher D, Cook DJ, Eastwood S, Olkin I, Rennie D, Stroup DF (1999) Improving the quolity of reports of meta-analyses of randomised controlled trials: the QUOROM statement. Lancet 354:1896-1900

Moll K (1953) Treatment of discus hernia with so-called "weightbath"therapy (in Hungarian). Orv Hetil 94:292-296

Nagy K, Berhés I, Kovács T, Kávási N, Somlai J, Bender T (2009a) Does balneotherapy with low radon concentration in water influence the endocrine system? A controlled non-randomized pilot study. Radiat Environ Biophys 48:311-315

Nagy K, Berhés I, Kovács T, Kávási N, Somlai J, Kovacs L, Barna I, Bender T (2009b) Study on endocronological effects of radon speleotherapy on respiratory diseases. Int J Radiat Biol 85:281-290

Olah M, Molnár L, Dobai J, Cs O, Fehér J, Bender T (2008) The effects of weightbath traction hydrotherapy as a component of complex physical therapy in disorders of the cervicaland lumbar spine: a controlled pilot study with follow-up. Rheumatol Int 28:749-756

Olah M, Koncz A, Fehér J, Kálmánczhey J, Oláh C, Balogh S, Nagy G, Bender T (2010) The effect of balneotherapy on C-reactive protein, serum cholesterol, triglyceride, total antioxidant status and HSP-60 levels. Int J Biometeorol 54:249-254

Olah M, Koncz Á, Fehér J, Kálmánczhey J, Oláh C, Nagy G, Bender T (2011) The effect of balneotherapy on antioxidant, inflammatory, and metabolic indices in patients with cardiovascular risk factors (hypertension and obesity)a randomised, controlled, follow-up study. Contemp Clin Trials 32:793-801

Pagourelias ED, Zorou PG, Tsaligopoulos M, Athyros VG, Karagiannis A, Efthimiadis GK (2011) Carbon dioxide balneotherapy and cardiovascular disease. Int J Biometeorol 55:657-663
Pittler MH, Karagülle MZ, Karagülle M, Ernst E (2006) Spa therapy and balneotherapy for treating low back pain: meta-analysis of randomized trials. Rheumatology 45:880-884

Shani J, Barak S, Levi D, Ram M, Schachner ER, Schlesinger T, Robberecht H, Van Grieken R, Avrach WW (1985) Skin penetration of minerals in psoriatics and guinea-pigs bathing in hypertonic salt solutions. Pharmacol Res Commun 17:501-512

Somlai J, Kavasi N, Szabó T, Várhegyi A, Kovács T (2007) The function of radon in curing respiratory diseases in the therapeutic cave of Tapolca. J Radioanal Nucl Chem 273:363-370

Sramek P, Simecková M, Janský L, Savlíková J, Vybíral S (2000) Human physiological responses to immersion into water of different temperatures. Eur J Appl Physiol 81:436-442

Szendi K, Gerencsér G, Murányi E, Varga C (2012) Mutagenic activity of peloids in the Salmonella Ames test. Applied Clay Sci 55:70-74

Szucs L, Ratko I, Lesko T, Szoor I, Genti G, Balint G (1989) Doubleblind trial on the effectiveness of the Puspokladany thermal water on arthrosis of the knee-joints. J R Soc Health 109:7-9

Tefner IK, Németh A, Lászlófi A, Kis T, Gyetvai G, Bender T (2012) The effect of spa therapy in chronic low back pain: a randomized controlled, single-blind, follow-up study. Rheumatol Int 32:31633169

van Tulder M, Furlan A, Bombardier C, Bouter L, Editorial Board of the Cochrane Collaboration Back Review (2003) Updated method guidelines for systematic reviews in the Cochrane Collaboration Back Review Group. Spine 28:1290-1299

Varga C (2011) The Balneology paradox. Int J Biometeorol 55:105-106

Varga C (2012) Balneoprevention: new approaches. Int J Biometeorol 56:195-197

Verhagen A, Bierma-Zeinstra S, Lambeck J, Cardoso JR, de Bie R, Boers M, de Vet HC (2008) Balneotherapy for osteoarthritis. A cochrane review. J Rheumatol 35:1118-1123

Zámbó L, Dékány M, Bender T (2008) The efficacy of alumcontaining ferrous thermal water in the management of chronic inflammatory gynaecological disorders - a randomized controlled study. Eur J Obstet Gynecol Reprod Biol 140:252-257 